ABDIMAS: Jurnal Pengabdian Masyarakat Universitas Merdeka Malang
Vol.5(2) Juli 2020, 123-130
UPPM

\title{
Pelatihan Keterampilan Herbarium Kering Modern bagi Guru dan Siswa di SMK Negeri 2 Batu
}

\author{
Tintrim Rahayu, Ari Hayati \\ Departemen Biologi, Fakultas MIPA, Universitas Islam Malang \\ Jl. Mayjen Haryono No.193, Malang, 65144, Indonesia
}

ARTICLE INFO:

Received: 2020-04-10

Revised: 2020-05-20

Accepted: 2020-06-02

Keywords:

Entrepreneurship;

Flower waste;

Herbarium; Oshibana

\section{ABSTRACT}

Batu as a tourism city produces a lot of vegetables, flowers, and ornamental plants. Many cut flower waste from sorting is not suitable for sale. Meanwhile, SMK Negeri 2 Batu has developed several products to be marketed and is a place for students to study entrepreneurship. However, there are problems in getting market demand due to intense competition. Therefore, production requires continuous innovation and creativity. This new method is offered to increase grades by teaching them the skills of a modern dry herbarium using waste flowers from the surrounding environment. The purpose of this activity is that the teachers and students of SMK Negeri 2 Batu have the knowledge and skills to create a modern dry herbarium with Oshibana techniques. Teaching is done by giving lectures, demonstrations, practices, and evaluations. The results show increased knowledge to utilize flower and leaf waste through manufacturing activities of modern dried herbarium with the Oshibana technique. The program also provides counseling on how to use wasted flowers and leaves that can be done properly. The training to make a modern dry herbarium which was later named "Beautiful Herbarium" was able to improve the knowledge and skills of participants. The "Beautiful Herbarium" extra-curriculum was held to ensure the sustainability of the program.

(C) 2020 Published by University of Merdeka Malang. This is an open access article distributed under the CC BY-SA 4.0 license (https://creativecommons.org/licenses/by-sa/4.0/)

How to cite: Rahayu, T., \& Hayati, A. (2020). Pelatihan Keterampilan Herbarium Kering Modern bagi Guru dan Siswa di SMK Negeri 2 Batu. Abdimas: Jurnal Pengabdian Masyarakat Universitas Merdeka Malang, 5(2), 123-130. https://doi.org/10.26905/abdimas.v5i2.3413

\section{PENDAHULUAN}

SMK Negeri 2 Batu yang yang berada di Kecamatan Bumiaji Kota Batu, merupakan lembaga pendidikan kejuruan menengah. Sekolah ini telah mengembangkan beberapa produk untuk dipasarkan dan sebagai wadah pembelajaran siswa dalam berwirausaha. Namun dalam hal pemasaran masih mengalami kendala, karena ketatnya persaingan. Potensi pariwisata dan sumber daya alam yang melimpah di Kota Batu, memotivasi SMK Negeri 2 Batu untuk membuat produk kewirausahaan seperti minuman sari apel dan juga produk souvenir berupa tanaman terrarium untuk dipasarkan sebagai wadah pembelajaran 
ABDIMAS: Jurnal Pengabdian Masyarakat Universitas Merdeka Malang

Volume 5, No 2, Juli 2020: 123-130

siswa untuk berwirausaha. Produk tersebut tidak dapat bersaing karena sudah banyak yang memproduksi bahkan lebih bagus dan menarik (Gambar 1). Oleh karena itu diperlukan inovasi dan kreatifitas untuk dapat bersaing dengan kualitas yang baik.
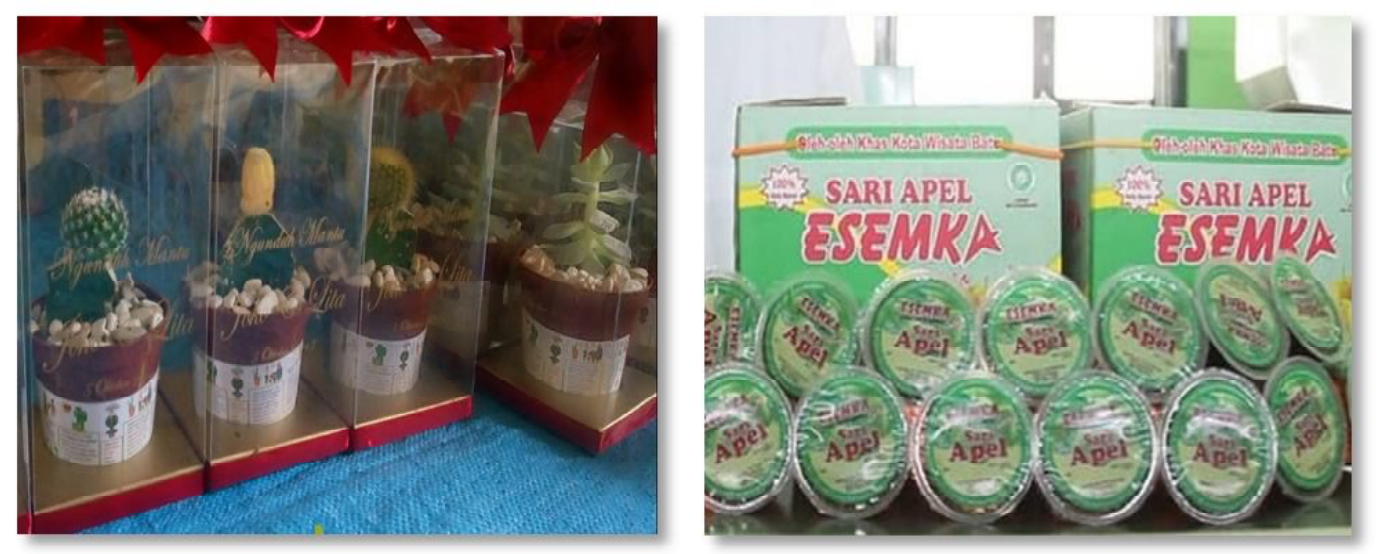

Gambar 1. Produk-produk kewirausahaan yang dihasilkan oleh siswa di SMK Negeri 2 Batu

Kota Batu merupakan kota pariwisata dengan sumber daya alam yang melimpah (Sukmana, 2006). Kota ini dikenal sebagai penghasil sayur mayur, bunga potong dan tanaman hias. Hasil survei lokasi di Desa Pandanrejo dan Desa Punten Kecamatan Bumiaji Kota Batu, ditemukan banyak limbah bunga potong hasil sortiran yang tidak layak jual, sehingga masyarakat membuang di tempat sampah. Komposisi sampah berguna untuk menghasilkan produk yang mempunyai nilai ekonomis dan berpotensi dimanfaatkan dengan lebih baik (Rahayu \& Sukmono, 2013). Mengingat Batu adalah kota pariwisata, maka memiliki potensi yang besar untuk mengembangkan produk hasil olahan limbah bunga potong tersebut.
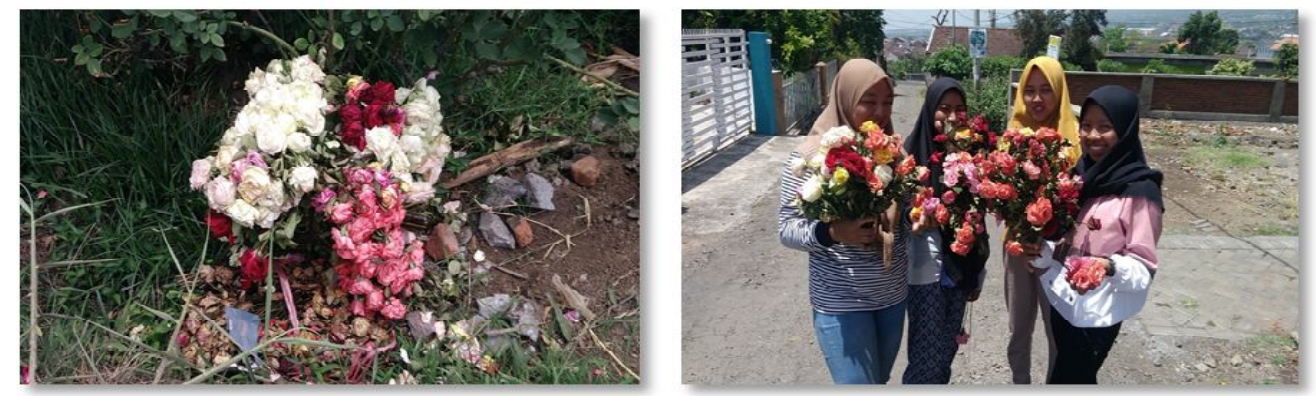

Gambar 2. Limbah bunga mawar yang telah dibuang dan tidak layak jual di perkebunan mawar

Dari permasalahan tersebut, Unisma Malang ingin menerapkan inovasi dan kreasi baru produk di SMK Negeri 2 Kota Batu dengan memanfaatkan limbah pertanian bunga potong dan tanaman hias melalui teknologi herbarium kering modern. Herbarium kering modern merupakan awetan tumbuhan yang dibuat dengan cara pengeringan, namun tetap terlihat warna asli dan ciri-ciri morfologinya (Muswita, 2019; Syafruddin \& Lestari, 2018). Dengan penerapan teknologi herbarium kering modern melalui pelatihan ini, diharapkan dapat menghasilkan produk kreasi seni seperti souvenir yang mempunyai nilai jual tinggi. Teknologi herbarium modern ini dikenal dengan Oshibana. 


\section{Pelatihan Keterampilan Herbarium Kering Modern bagi Guru dan Siswa di SMK Negeri 2 Batu \\ Tintrim Rahayu, Ari Hayati}

Oshibana adalah seni bunga tekan yang berasal dari Jepang dikenal sejak abad ke-16. Seni tersebut diwariskan secara turun temurun dari generasi ke generasi hingga kini. Diyakini, kelahiran Oshibana berawal dari keinginan masyarakat Jepang untuk mengabadikan keindahan bunga sakura yang hanya bisa dinikmati ketika musim semi. Negara Jepang mengenal 4 musim. Tidak semua daun dan bunga dapat bertahan di keempat musim tersebut. Musim gugur dan musim dingin akan merontokkan hampir seluruh bunga dan daun sedangkan musim semi dan musim panas akan diwarnai oleh mekarnya bunga dan bertumbuhnya dedaunan (Aderina, 2012). Agar tetap dapat menikmati indahnya bunga sakura saat musim gugur, mereka mengeringkan dan menyimpannya lalu mengkreasikan dan mengaplikasikannya dalam berbagai bentuk. Untuk mengeringkan bunga, mereka menggunakan teknik press dimana bunga dan daunnya tidak berubah warna dalam waktu yang lama (Andini et al., 2014). Dari sinilah muncul seni oshibana yang akhirnya menyebar ke seluruh penjuru negeri. Oshibana berasal dari dua kata, yakni 'oshi' yang berarti tekan, dan 'bana/hana' yang berarti bunga. Jadi secara harafiah, oshibana berarti bunga yang ditekan/dipress. Secara umum, oshibana dapat didefinisikan sebagai seni merangkai bunga press yang diaplikasikan dalam berbagai kreasi yang unik dan menarik.

Herbarium adalah suatu koleksi spesimen tumbuhan yang diawetkan berikut data terkait yang digunakan untuk keperluan penelitian ilmiah (Rabeler, 2019: Royal Botanic Garden Edinburgh, 2016). Istilah herbarium dapat juga merujuk pada bangunan atau ruangan di mana spesimen-spesimen tersebut disimpan, atau pada lembaga ilmiah yang tidak hanya menyimpan, tetapi juga menggunakannya untuk penelitian. Dalam bidang penelitian biologi, dikenal istilah awetan kering dan awetan basah. Keduanya sama-sama digunakan sebagai media pembelajaran dan penelitian (Aikio, Duncan, \& Hulme, 2010; Kalema, 2008).

Penerapan teknologi herbarium kering modern dengan teknik Oshibana atau disebut dengan bunga press. Teknik ini dibuat dengan metode Oshibana yang berasal dari negara Jepang, yaitu mengeliminir kandungan air pada bunga dengan cara press, didapatkan warna yang sesuai dengan aslinya dalam keadaan kering tanpa menggunakan bahan kimia sehingga ramah lingkungan. Pengeringan harus segera dilakukan karena jika terlambat akan mengakibatkan material herbarium rontok daunnya dan cepat menjadi busuk. Sesuai dengan arti namanya, seni Oshibana ini dapat membantu dalam mengabadikan keindahan flora yang berbasis konservasi (Juliansyah et al., 2013). Hasil dari penerapan teknologi herbarium kering modern dengan teknik Oshibana, dapat dijadikan beberapa karya seni seperti lukisan, aksesoris kalung, gelang, liontin, bros, jepit rambut, gantungan kunci dan pembatas buku yang mempunyai nilai jual tinggi (Gambar 3).
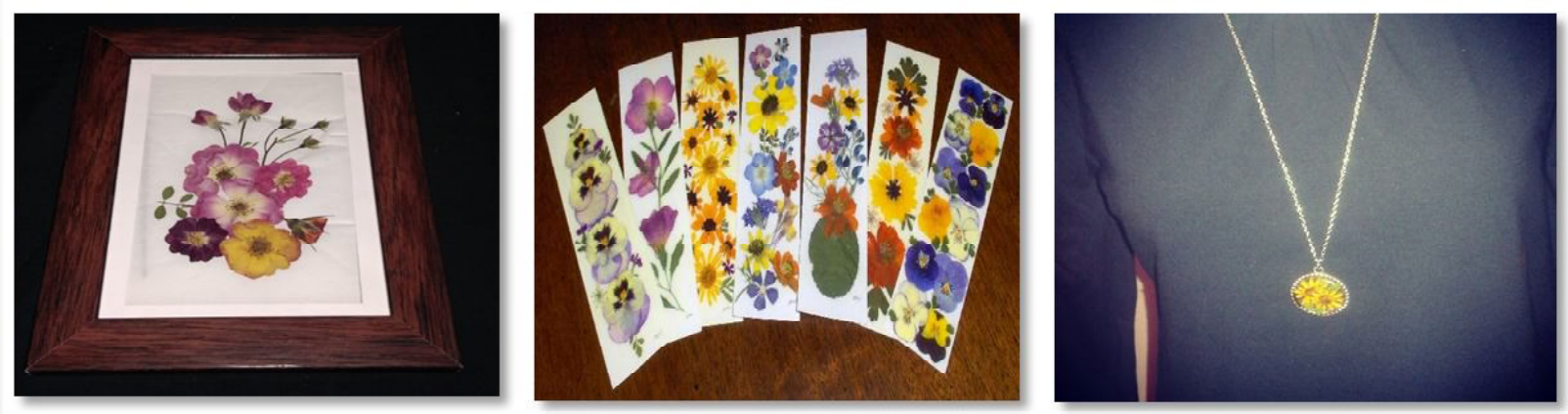

Gambar 3. Produk dari teknologi herbarium kering dengan teknik Oshibana berupa

"Herbarium Indah", pembatas buku, dan liontin 


\section{ABDIMAS: Jurnal Pengabdian Masyarakat Universitas Merdeka Malang}

Volume 5, No 2, Juli 2020: 123-130

Program ini bertujuan memberikan pengetahuan inovasi baru pengolahan produk memanfaatkan limbah pertanian bunga diharapkan SMK Negeri 2 Batu diharapkan mampu meningkatkan kemandirian, serta meningkatkan kreativitas dalam berwirausaha terutama kepada peserta didik. Pelaksanaan program adalah dengan memberikan keterampilan dan keahlian dalam pengolahan limbah bunga hias sehingga bisa membantu mereka dalam pengembangan kemandirian dan kewirausahaan serta menumbuhkan rasa percaya diri dalam menghadapi masa depan.

Dari kegiatan ini diharapkan akan diperoleh hasil sebagai berikut: (1) melalui pelatihan ini guru dan siswa SMK Negeri 2 Batu dapat memanfaatkan limbah bunga yang ada di lingkungan sekitar mereka. (2) Melalui pelatihan ini guru dan siswa SMK Negeri 2 Batu memiliki pengetahuan dan keterampilan pembuatan herbarium kering modern dengan teknik Oshibana. (3) Memberikan peluang untuk menciptakan wirausahawan muda baru (entrepreneurship).

Kegiatan ini diperoleh target luaran sebagai berikut: (1) terbentuknya kelompok-kelompok orang membuat berbarium kering modern dengan teknik Oshibana dengan memanfaatkan limbah pertanian bunga potong. (2) Peserta didik SMK Negeri 2 Batu memiliki peluang mendapatkan penghasilan tambahan dengan menjual produk hasil dari herbarium kering dengan teknik Oshibana. (3) Menghasilkan karya seni dari herbarium kering modern dengan teknik Oshibana yang memiliki informasi ilmiah sehingga dapat didonasikan di sekolah sebagai pembelajaran identifikasi tumbuhan. (4) Mampu menciptakan Standar Operasional Prosedur (SOP) dalam pembuatan herbarium kering dengan teknik Oshibana.

\section{METODE}

Metode yang digunakan berupa pelatihan yang bertujuan untuk menghasilkan pengetahuan dan keterampilan. Untuk melihat tingkat keberhasilan pelatihan peserta dibagikan kuisioner sebelum dan sesudah pelaksanaan dengan teknik random sampling. Dari peserta 100 orang diberi kuisioner 35 orang. Kegiatan dimulai dengan mengidentifikasi tingkat pengetahuan peserta tentang pengawetan limbah bunga dan penataan menjadi "Herbarium Indah" dengan cara melakukan pretest tertulis. Jumlah soal yang diujikan berjumlah 12 soal. Setelah pretest dilakukan, selanjutnya diberikan pelatihan kepada peserta. Materi pelatihan meliputi,

Penyuluhan yang bertujuan untuk memberikan ilmu dan wawasan baru kepada guru dan siswa SMK Negeri 2 Batu tentang wirausaha dan peluang usaha rumahan, sehingga terbuka pikiran serta tumbuh minat dan motivasi dalam diri mereka untuk berwirausaha. Penyuluhan ini disampaikan dalam bentuk ceramah dan tanya jawab kepada peserta: (1) penyuluhan tentang pemanfaatan limbah pertanian terutama bunga potong yang ramah lingkungan. (2) Pemberian materi tentang teknologi herbarium kering modren dengan teknik Oshibana. (3) Penjelasan tentang proses pembuatan dan pengemasan produk.

Pelatihan yang dilaksanakan menggunakan metode experiential learning (Azizi, Susanto, \& Pambudi, 2013) yang artinya melibatkan peserta secara aktif di setiap sesi pelatihan sehingga peserta belajar dan mengalami secara langsung setiap proses selama pelatihan. Hal tersebut dilakukan dengan cara melakukan ceramah dan tanya jawab antara peserta dan trainer, melakukan demonstrasi dan peserta disuruh melakukan praktek langsung terhadap pembuatan herbarium ini. Hal ini bertujuan untuk memberikan keterampilan tentang cara produksi dan pengemasan yang dilanjutkan dengan pembuatan dan pengemasan produk tersebut. Pelatihan dilaksanakan sampai semua peserta dapat mempraktekkan sendiri. Materi pertama 


\section{Pelatihan Keterampilan Herbarium Kering Modern bagi Guru dan Siswa di SMK Negeri 2 Batu \\ Tintrim Rahayu, Ari Hayati}

adalah pelatihan teknik dasar pembuatan herbarium kering modern dengan teknik Oshiban yaitu proses pengeringan spesimen tumbuhan dengan cara press. Produk yang dihasilkan adalah spesimen tumbuhan kering dengan mempertahankan warna asli. Aplikasi hasil dari herbarium kering teknik Oshiban yaitu membuat pembatas buku dan lukisan bingkai.

\section{HASIL DAN PEMBAHASAN}

Kegiatan PKM di SMK 2 Batu berbasis keterampilan herbarium kering modern ini dilaksanakan dalam beberapa tahap. Tahap pertama. Pada tahap pertama ini pelatihan dilaksanakan di SMK Negeri 2 Batu, yang dihadiri oleh peserta dari kalangan guru dan siswa. Pada tahap pertama ini, materi yang diberikan antara lain: (1) tentang teori dasar herbarium dan permasaahanya. (2) Materi dasar teknik pembuatan herbarium kering modern. (3) Pelatihan aplikasi pembuatan produk pembatas buku dari herbarium (Gambar 4). Pada sesi pertama, peserta diberikan pengetahuan dasar tentang herbarium, jenisjenis herbarium dan permasalahanya. Tim PKM menjelaskan bahwa herbarium merupakan bagian tumbuhan yang dikeringkan untuk dijadikan berbagai macam keperluan seperti obat, identifikasi dan koleksi. Akan tetapi permasalahan muncul terhadap herbarium seperti warna yang berubah sehingga tidak identik dengan warna aslinya. Sehingga perlu teknik atau metode pembuatan herbarium yang bisa mempertahankan warna asli untuk jangka waktu yang lama.

Pada sesi pelatihan yang kedua, tim PKM Unisma memberikan materi pelatihan teknik dasar pembuatan herbarium kering modern dengan teknik press yang menggunakan kertas buram, kertas hisap, busa spon dan plastic klip dalam pembuatanya. Dalam metode ini tim PKM Unisma mengadopsi teknik Oshibana dari Jepang dengan mengeliminir kandungan air pada spesimen tumbuhan dengan cara press dalam kondisi kedap udara. Sehingga didapatkan hasil herbarium kering yang bisa mempertahankan warna aslinya.
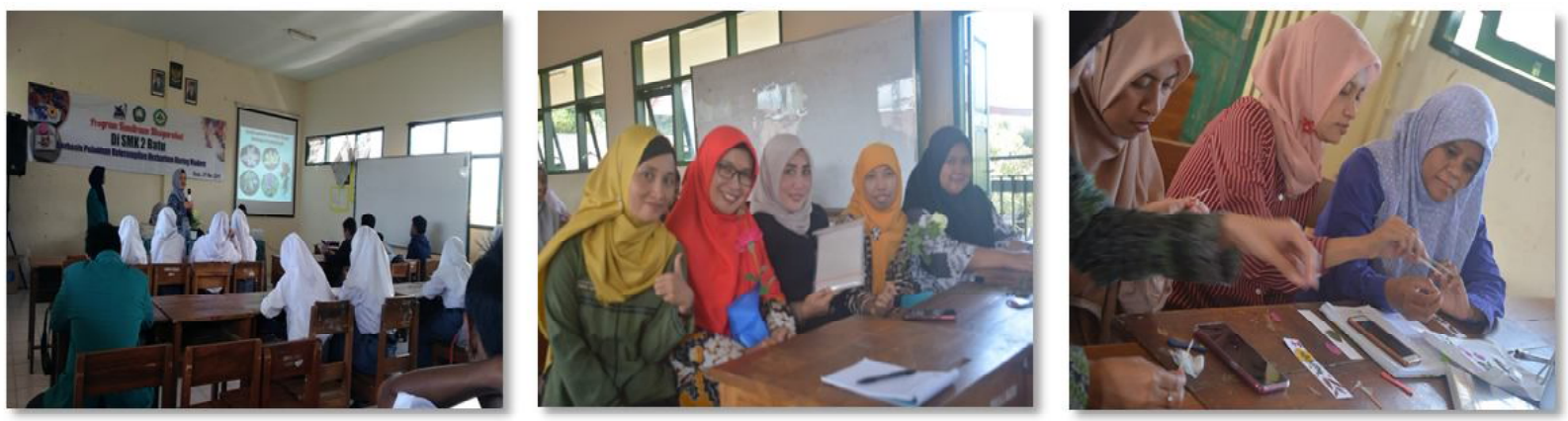

Gambar 4. Penyampaian materi pemanfaatan limbah bunga sortiran menjadi keterampilan herbarium dalam bentuk "Herbarium Indah" dan pembatas buku

Selanjutnya pada sesi pelatihan yang ketiga adalah aplikasi pembuatan pembatas buku dari herbarium kering modern. Para peserta diajarkan bagaimana proses tahapan dalam pembuatan pembatas buku. Pada sesi ini alat bahan yang digunakan adalah kertas buffalo, herbarium kering, lem, plastik laminating, alat laminating, pita, dan gunting. Para sesi pelatihan ini para peserta diberi kesempatan untuk membuat sendiri sesuai dengan keinginanya. 
ABDIMAS: Jurnal Pengabdian Masyarakat Universitas Merdeka Malang

Volume 5, No 2, Juli 2020: 123-130

Tahap kedua. Pada pelatihan tahap kedua Tim PKM memberikan pelatihan untuk membuat produk karya seni herbarium dengan teknik penyimpanan di pigura atau yang disebut "Herbarium Indah" (Gambar 5). Alat dan bahan yang digunakan adalah pigura ukuran A5, plastik aluminium foil, kertas hisap, busa spon, silica gel, lem, vacuum udara dan yang penting adalah spesimen kering herbarium. Pada tahap ini peserta menyiapkan bahan kering dari rumah hasil pengeringan pada pelatihan tahap pertama untuk di aplikasikan pada tahap ke dua ini. Perlu diketahui produk pigura indah ini bernilai seni tinggi sekligus bernilai ekonomi tinggi, mengingat pembuatanya memerlukan waktu yang relatif lama dan membutuhkan keuletan dan ketekunan. Teknik pembingkaian ini merupakan teknik penyimpanan spesimen herbarium kering di dalam bingkai kaca yang bisa menampilkan keindahan bunga dalam keadaan kering.
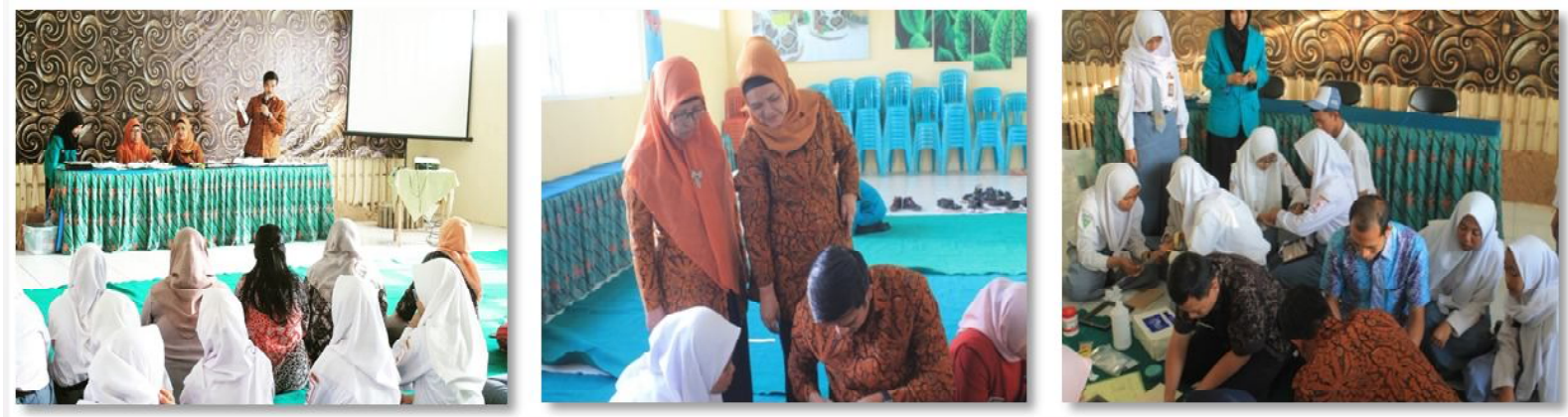

Gambar 5. Penyampaian materi aplikasi penyimpanan di pigura atau yang disebut "Herbarium Indah"

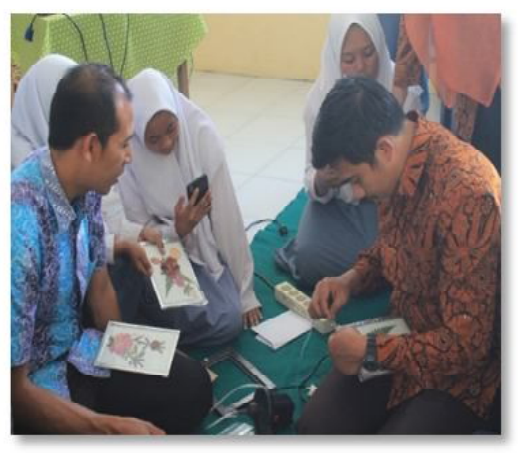

Gambar 6. Pelatihan aplikasi penyimpanan di pigura atau yang disebut "Herbarium Indah"

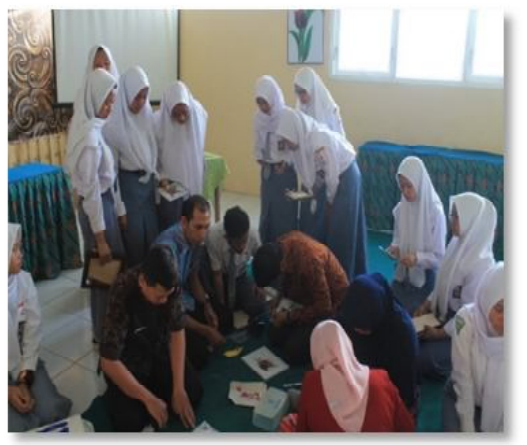

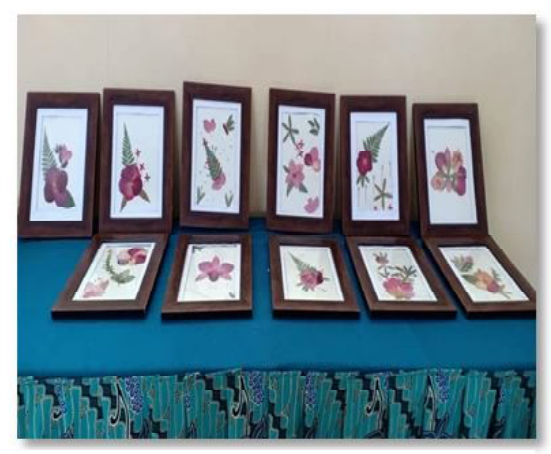

Gambar 7. Hasil pelatihan "Herbarium Indah"

Tahap ketiga. Tahap ini adalah kegiatan pengeringan limbah bunga, menata untuk pembatas buku, dan menata untuk pigora sehingga nampak seperti lukisan. Luaran pertama kegiatan ini berupa realisasi ekstra-kurikuler "Herbarium Indah", yang bertujuan untuk menjamin kontinyuitasnya program. Ekstra-kurikuler ini diadakan dengan pertimbangan karena masih banyak inovasi dan kreatifitas yang belum terungkap, seperti pembuatan gantungan kunci, asesoris dan lain sebagainya. Kepala sekolah menghendaki terus menerus tercipta hal-hal baru sehingga variasi produk dapat ditingkatkan, mengingat produk-produk tersebut diperlukan bagi beberapa penyedia souvenir di lokasi pariwisata dan hotel-hotel. 


\section{Pelatihan Keterampilan Herbarium Kering Modern bagi Guru dan Siswa di SMK Negeri 2 Batu Tintrim Rahayu, Ari Hayati}
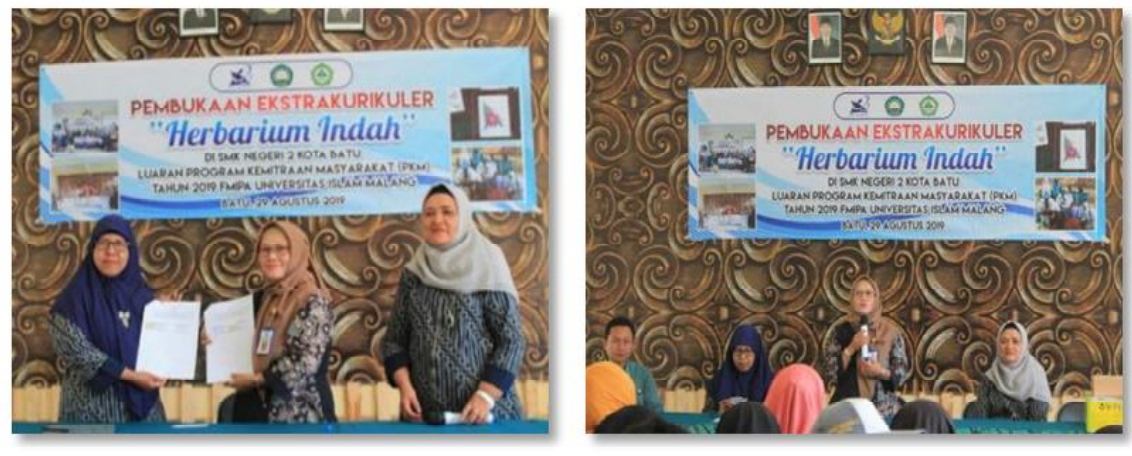

Gambar 8. Pembukaan ekstra-kurikuler “Herbarium Indah”di SMK Negeri 2 Batu

Hasil respon peserta berdasarkan kuisioner yang dibagikan pre dan post menunjukkan hampir seluruh peserta tidak memahami tentang herbarium. Namun setelah mengikuti bimbingan teknis dan pendampingan secara langsung menunjukkan peningkatan pengetahuan tentang penggunaan dan pemanfaatan sampah bunga dan daun menjadi produk yang berharga. Peserta yang terdiri dari guru dan siswa berjumlah 100 orang dibagi dalam 20 kelompok. Semua peserta mengikuti penyuluhan dan pelatihan dengan memperoleh hasil yang baik. Terjadi perubahan yang signifikan pada pengetahuan dan keterampilan dalam membuat herbarium kering modern.

Pelatihan yang telah dilaksanakan menggunakan metode experiential learning, yang artinya melibatkan peserta secara aktif di setiap sesi pelatihan sehingga peserta belajar dan mengalami secara langsung setiap proses selama pelatihan. Hal tersebut dilakukan dengan cara melakukan ceramah dan tanya jawab antara peserta dan trainer, melakukan demonstrasi dan peserta disuruh melakukan praktek langsung terhadap pembuatan herbarium ini. Keberhasilan pelatihan ini dipengaruhi oleh banyak hal, antara lain kompetensi trainer dalam memberikan materi, kelengkapan sarana dan peralatan untuk melakukan praktek, antusiasme peserta saat mengikuti pelatihan, hal ini diketahui dari hasil observasi selama pelatihan berlangsung. Peserta pelatihan terlihat aktif dalam memberikan argumen terhadap materi pelatihan melalui pertanyaan-pertanyaan. Selain itu, peserta juga aktif terlibat dalam praktek dan diskusi yang diadakan. Peserta juga memberikan penilaian terhadap proses pelatihan yang berlangsung pada akhir program pelatihan.

\section{SIMPULAN DAN SARAN}

Penyuluhan tentang pemanfaatan limbah bunga dan daun dapat dilaksanakan dengan baik. Pelatihan pembuatan herbarium kering modern yang kemudian dinamakan "Herbarium Indah" mampu meningkatkan pengetahuan dan keterampilan peserta. Program ini dilakukan kepada guru dan siswa SMK Negeri 2 Batu melalui penyuluhan dimana peserta dapat memanfaatkan limbah bunga yang ada di lingkungan sekitar mereka. Guru dan siswa SMK Negeri 2 Batu memiliki pengetahuan dan keterampilan pembuatan herbarium kering modern dengan teknik Oshibana. Sehingga dapat memberikan peluang untuk menciptakan wirausahawan muda baru (entrepreneurship). Hasil pelatihan yang didapatkan oleh peserta mampu melakukan inovasi dan kreativitas yang lebih baik lagi. Kedepannya diperlukan pelatihan kewirausahaan bagi peserta sehingga keterampilan yang sudah didapatkan mampu dipergunakan dalam berwirausaha. Dalam menjamin kontinyuitas pelaksanaan PKM ini maka dibuka ekstrakulikuler yang diberi nama "Her- 
ABDIMAS: Jurnal Pengabdian Masyarakat Universitas Merdeka Malang

Volume 5, No 2, Juli 2020: 123-130

barium Indah", yang diharapkan mampu menciptakan SOP dalam pembuatan herbarium kering dengan teknik Oshibana. Program ini menghasilkan karya seni dari herbarium kering modern dengan teknik Oshibana yang memiliki informasi ilmiah sehingga dapat didonasikan di sekolah sebagai pembelajaran identifikasi tumbuhan

\section{UCAPAN TERIMAKASIH}

Ucapan terimakasih ditujukan kepada pemerintah Indonesia yang telah membiayai kegiatan ini, melalui Ristek Dikti tahun 2019, dalam Program Kemitraan Masyarakat (PKM) di Universitas Islam Malang

\section{DAFTAR PUSTAKA}

Aderina, S. (2012). Oshibana Seni Bunga Press dari Jepang. Jakarta: Demedia Pustaka.

Aikio, S., Duncan, R. P., \& Hulme, P. E. (2010). Herbarium records identify the role of long-distance spread in the spatial distribution of alien plants in New Zealand. Journal of Biogeography, 37(9), 1740-1751. https://doi.org/10.1111/j.1365-2699.2010.02329.x

Andini, W., Darmawan M. B., Harahap, Y. P., Hasanah, U., \& Septiany R. (2014). Pendidikan kreatif seni bunga tekan (Oshibana) bagi siswa SMPIT Nurul Fajar sebagai sarana mencintai biodiversitas tanaman Indonesia. Laporan akhir PKM-M. Institut Pertanian Bogor.

Azizi, A., Susanto, \& Pambudi, D. S. (2013). Penerapan model experiental learning untuk meningkatkan hasil belajar pokok bahasan unsur lingkaran siswa Kelas VIII SMP Salafiyah Miftahul Huda Jenggawah Tahun Ajaran 2012/2013. Kadikma, 4(3), 113-120

Juliansyah, A., Maulana, M. I., Hasbi, M., Andini, W., \& Susanti, S. (2013). Kreasi biodiversitas tanaman sebagai peluang greenpreneurship industri kreatif berbasis edukasi-konservasi. Laporan PKMK. IPB University Bogor.

Kalema, J. (2008). The use of herbarium plant databases in identifying areas of biodiversity concentration: the case of family Acanthaceae in Uganda. African Journal of Ecology, 46(1), 125-126. https://doi.org/10.1111/j.1365-2028.2008.00942.x

Muswita, Yelianti, U., Sukmono, T., Harlis, \& Kartika, W. D. (2019). Pelatihan pembuatan herbarium sebagai media pembelajaran biologi di SMAN 11 Muaro Jambi. Jurnal Karya Abdi Masyarakat 3(2), 170-175. https://doi.org/10.22437/jkam.v3i2.8479

Rabeler, R. K., Svoboda, H. T., Thiers, B., Prather, I. A., Macklin, J. A., Lagomarsino, L. P., Majure, L. C., \& Ferguson, C. J. (2019). Herbarium Practices and Ethics, III. Systimatic Botani, 44(1), 7-13

Rahayu, D. E., \& Sukmono, Y. (2013). Kajian potensi pemanfaatan sampah organik pasar berdasarkan karakteristiknya (Studi Kasus Pasar Segiri Kota Samarinda). Jurnal Sains \& Teknologi Lingkungan, 5(2), 77-90. https://doi.org/10.20885/jstl.vol5.iss2.art2

Royal Botanic Garden Edinburgh. (2016). What is a herbarium? https://www.rbge.org.uk/. Diakses tanggal 25 Maret 2019.

Sukmana, Oman. 2006. Model Pengelolaan Lingkungan Binaan Desa Wisata Bunga pada Kawasan Ekowisata (Studi di Desa Sidomulyo, Kota Batu). Malang: Lemlit UMM.

Syafruddin \& Lestari, I. D. (2018). Pelatihan pembuatan herbarium sebagai media pembelajaran keanekaragaman hayati pada kelas VIII SMP Negeri 3 Moyo Hulu tahun 2017. Jurnal Kependidikan, 2(2), 66-70. https://doi.org/10.31227/osf.io/hetjs 